Gerstley, and Blumberg, 1969; Nowosławski, Brzosko, Madaliński, and Krawczyński, 1970; Nelson, Barker, and Danovitch, 1970; Ahmed, Huang, and Spence, 1971). It is hoped that an extension of this study by these techniques will provide further support of an association of these two types of cellular change with the presence of H.A.A.

We thank Dr. E. P. Maynard for his assistance and advice during the early part of this study and Professor R. A. B. Drury for technical facilities in the department of pathology, Makerere University, Kampala. This work is supported in part by Contract No. PH 43-67-1343 from Chemotherapy, National Cancer Institute, National Institutes of Health, Bethesda, Maryland, U.S.A. One of us (P.P.A.) gratefully acknowledges further financial assistance from Dr. A. Linsell, International Agency for Research on Cancer, Regional Centre, Nairobi, and from the Wellcome Trust, London.

This work was presented in part at an International Symposium on Liver Cancer, Kampala, Uganda, on 5 July 1971.

Requests for reprints should be addressed to Dr. P. P. Anthony, Bland-Sutton Institute of Pathology, Middlesex Hospital Medical School, London W1P 7PP.

\section{References}

Ahmed, M. N., Huang, S., and Spence, L. (1971). Archives of Pathology, 92, 66.

Barker, L. F., and Murray, R. (1971). Fournal of the American Medical Association, 216, 1970.

Blumberg, B. S., Sutnick, A. I., and London, W. T. (1970). American fournal of Medicine, 48, 1 .

Cook, G. C., and Hutt, M. S. R. (1967). British Medical fournal, 3, 454

Gall, E. A. (1960). American fournal of Pathology, 36, 241.

Gocke, D. J., and Howe, C. (1970). Fournal of Immunology, 104, 1031

Lieber, C. S., and Rubin, E. (1969). New England fournal of Medicine, 280, 705.

Maynard, E. P., Sadikali, F., Anthony, P. P., and Barker, L. F. (1970). Lancet, $2,1326$.

Millman, I., Zavatone, V., Gerstley, B. J. S., and Blumberg, B. S. (1969). Nature, 222, 181.

Nelson, J. M., Barker, L. F., and Danovitch, S. H. (1970). Lancet, 2, 773. Nowostawski, A., Brzosko, W. J., Madaliński, K., and Krawczynski, K. (1970). Lancet, 1,494 .

Popper, H. (1966). In Controversy in Internal Medicine, ed. F. J. Ingelfinger, A. S. Relman, and M. Finland, p. 233. Philadelphia, Saunders.

Prince, A. M., Leblanc, L., Krohn, K., Masseyeff, R., and Alpert, M. E. (1970). Lancet, 2, 717.

Scheuer, P. J. (1968). Liver Biopsy Interpretation. London, Bailliere, Tindall and Cassell.

Shaper, A. G. (1970). Tropical and Geographical Medicine, 22, 161.

Sherlock, S. (1968). Diseases of the Liver and Biliary System, 4th edn. Oxford, Blackwell Scientific.

Shulman, N. R. (1970). American fournal of Medicine, 49, 669

Shulman, N. R. (1970). American fournal of Medicine, 49, 669.
Shulman, N. R., and Barker, L. F. (1969). Science, 165, 304.

Steiner, P. E., and Davies, J. N. P. (1957). British fournal of Cancer, 11, 523.

Vyas, G. N., and Shulman, N. R. (1970). Science, 170, 332.

\title{
Sebum Excretion in Acromegaly
}

\author{
J. L. BURTON, \\ L. J. LIBMAN, \\ W. J. CUNLIFFE,
}

R. WILKINSON,

R. HALL,

S. SHUSTER

British Medical fournal, 1972, 1, 406-408

\section{Summary}

The sebum excretion rate (S.E.R.) was measured in 20 patients with acromegaly. Eleven were untreated at the time of the measurement and nine had previously undergone surgical hypophysectomy or had received pituitary irradiation by yttrium-90 or radiotherapy. In five patients the S.E.R. was measured before and after such treatment. The mean S.E.R. in the untreated acromegalics was much greater than in a normal population and decreased significantly after successful pituitary ablation. No significant decrease in mean S.E.R. occurred in the group of patients with a poor clinical response to ablation. The correlations between S.E.R. and log serum growth hormone, plasma 11-hydroxycorticosteroid levels, and heel-pad thickness were significant, but there was no significant correlation between S.E.R. and serum protein-bound iodine levels. This suggests that the changes in S.E.R. were due to pituitary ablation but could not necessarily be attributed solely to changes in growth hormone, thyroid-stimulating hormone, or adrenocorticotrophic hormone. The association between the clinical state of the acromegaly and the S.E.R. was better than the association between acromegaly and serum growth hormone. We conclude that the S.E.R. is a useful addition to the clinical and endocrinological data used in assessing acromegaly.

\section{Royal Victoria Infirmary, Newcastle upon Tyne NE1 4LP}

J. L. BURTON, M.D., M.R.C.P., Wellcome Dermatological Research Fellow L. J. LIBMAN, B.SC., M.R.C.P., Medical Registrar (Present address: University College Hospital, London W.C.1)

W. J. CUNLIFFE, M.D., M.R.C.P., Consultant Dermatologist (Present address: General Infirmary, Leeds LS1 3EX)

R. WILKINSON, B.SC., M.R.C.P., Lecturer in Medicine

R. HALL, M.D., F.R.C.P., Professor of Medicine

S. SHUSTER, PH.D., F.R.C.P., Professor of Dermatology

\section{Introduction}

The endocrine glands play an important part in the control of sebaceous gland function. It has been shown in the rat that the pituitary has an important action in this respect although its exact role has not yet been fully elucidated (Lasher et al., 1954; Nikkari and Valavaara, 1969; Ebling et al., 1970; Thody and Shuster, 1970). We therefore investigated the effect of pituitary hyperfunction on the human sebaceous gland by studying patients with acromegaly.

\section{Method}

Seven men and 13 women aged 36-67 years with acromegaly were studied. The diagnosis of acromegaly was made after clinical and radiological assessment and measurement of serum growth hormone. Eleven patients were untreated and nine had previously been treated as follows: five had received a pituitary implant of yttrium- 90 calculated to deliver a dose of 50,000 rads; one had received an yttrium implant five years after radiotherapy to the pituitary; one had undergone surgical hypophysectomy followed by radiotherapy; and two had received only radiotherapy.

The sebum excretion rate (S.E.R.) was measured in each patient by the method of Strauss and Pochi (1961) as modified by Cunliffe and Shuster (1969). Many of the patients complained of excessive sweating in warm weather. Because the uptake of sebum by the collection papers is affected by excessive sweating the S.E.R. was estimated only at room temperature of $18^{\circ} \mathrm{C}$ or less and the subjects were given no warm drinks during the sebum collection.

In five patients the S.E.R. was measured twice (once before and once after treatment), at an interval of 8 to 20 months. The measurement was made before and after the first yttrium implant in two patients and before and after the second implant in three, the first implant having been adjudged clinically unsuccessful. The S.E.R. was measured once only in the other 15 patients. 
The success of pituitary ablation in controlling the acromegaly was assessed by one of us (R.H.). The features which were taken into account in assessing the response were (a) change in facial appearance, as judged by the patient, his relatives, and the physician with the aid of serial photographs; $(b)$ change in size of hands and feet assessed subjectively; and (c) change in severity of headache. The assessment was made on clinical grounds only and the clinician was unaware of the results of the endocrine investigations or the S.E.R. at the time of his clinical evaluation. For the purpose of this communication the response to treatment was classified as "poor" if further pituitary ablation was considered necessary and "good" if no further ablation was contemplated.

The following radiological and endocrinological investigations were also performed each time the S.E.R. was measured. Heelpad thickness was measured radiographically by the method of Steinbach and Russell (1964). Serum growth hormone concentration was determined by radioimmunoassay (Hartog et al., 1964), the Medical Research Council A growth hormone preparation being used as a standard. Growth hormone measurements were made in fasting serum and serially during the two hours following $50 \mathrm{~g}$ of glucose given orally. The serum protein-bound iodine (Technicon Methodology N-56) and 9 a.m. plasma 11-hydroxycorticoids (cortisol) (Mattingly, 1962) were also measured.

The S.E.R.s were measured in 18 men and 54 women controls of the same age range as the acromegalic patients. The control subjects were healthy volunteers and patients attending the skin outpatient department with benign localized lesions such as papillomata.

Three of the patients were receiving testosterone therapy for impotence at the time of the S.E.R. measurement.

\section{Results}

The mean S.E.R. in the four men and seven women with acromegaly who were untreated was significantly increased compared with the control subjects $(P<0.01$ for men and $\mathrm{P}<0.001$ for women) (Fig. 1). Of the nine treated patients,

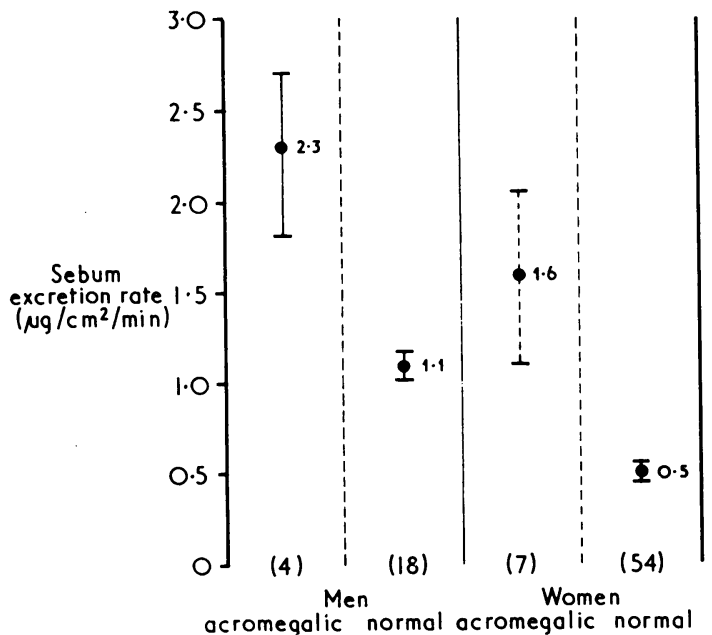

FIG. 1-Sebum excretion rates (mean \pm S.E. of mean) in untreated acromegalics and a normal population.

four were adjudged to have had a poor result from pituitary ablation, four had a good result, and one had an intermediate response. The S.E.R.s in the three main clinical groups (untreated, good response, and poor response) are shown in Fig. 2. There was a good association between S.E.R. and the clinical assessment of activity of the acromegaly. The mean S.E.R. in the untreated patients $\left(1.84 \pm 0.20 \mu \mathrm{g} / \mathrm{cm}^{2} / \mathrm{min}\right)$ was significantly greater $(P<0.002)$ than in the good response group $(0.36 \pm$

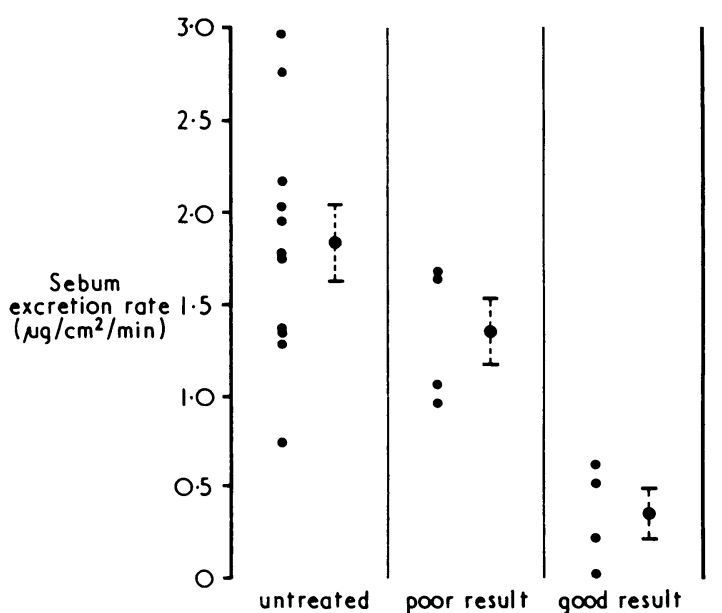

FIG. 2-Sebum excretion rates and mean \pm S.E. of mean in untreated and treated acromegalics. The terms "poor result" and "good result" refer to the clinical response to pituitary ablation.

$\left.0.27 \mu \mathrm{g} / \mathrm{cm}^{2} / \mathrm{min}\right)$, but not significantly different $(P>0.05)$ from the group with a poor response to ablation $(1.35 \pm 0.19 \mu \mathrm{g} /$ $\mathrm{cm}^{2} / \mathrm{min}$ ). The one patient with an intermediate response to treatment had a low S.E.R. of $0.51 \mu \mathrm{g} / \mathrm{cm}^{2} / \mathrm{min}$.

The minimum concentrations of serum growth hormone achieved during suppression by a glucose tolerance test are shown in Fig. 3. These growth hormone results appeared to be log-normally distributed. When their logarithms were analysed a significant difference was noted between the untreated and good response groups $(P<0.001)$.

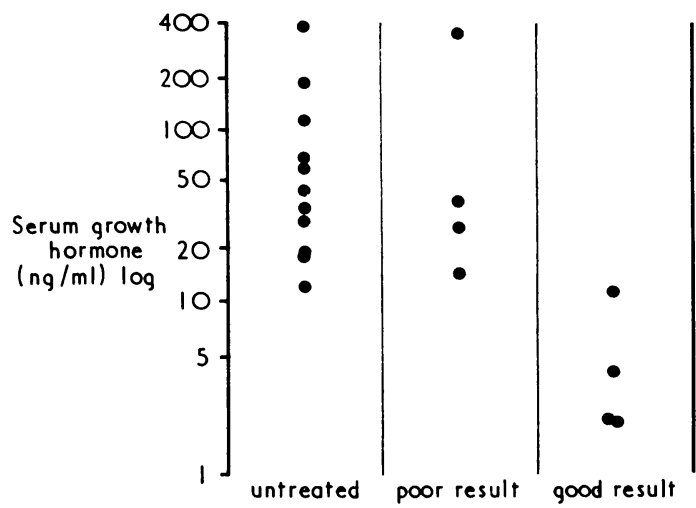

FIG. 3-Serum growth hormone concentrations in treated and untreated acromegalics.

There was no significant difference between the untreated patients and the group with a good response as regards the mean serum protein-bound iodine and plasma cortisol concentrations.

The S.E.R. before and after treatment in the five patients in whom two measurements were made is shown in the Table.

Sebum Excretion Rates and Growth Hormone Concentrations before and after Treatment in Five Patients having had Two Sebum Measurements

\begin{tabular}{|c|c|c|c|c|c|c|c|}
\hline \multirow{2}{*}{$\begin{array}{l}\text { Case } \\
\text { No. }\end{array}$} & \multicolumn{3}{|c|}{ S.E.R. } & \multicolumn{3}{|c|}{$\begin{array}{l}\text { Min. Growth Hormone } \\
\text { during G.T.T. }\end{array}$} & \multirow{2}{*}{$\begin{array}{l}\text { Response } \\
\text { to } \\
\text { Treatment }\end{array}$} \\
\hline & $\begin{array}{l}\text { Before } \\
(\mu \mathrm{g} / \mathrm{cr}\end{array}$ & $\begin{array}{c}\text { After } \\
\text { (min) }\end{array}$ & $\underset{(\%)}{\text { Change }}$ & Befor & $\begin{array}{l}\text { After } \\
\text { l) }\end{array}$ & $\underset{(\%)}{\text { Change }}$ & \\
\hline $\begin{array}{l}1 \\
2 \\
3 \\
4 \\
5\end{array}$ & $\begin{array}{l}2 \cdot 18 \\
0.97 \\
1.79 \\
1.68 \\
1.07\end{array}$ & $\begin{array}{l}1 \cdot 15 \\
0.68 * \\
0.51 \\
0.56 \\
0.08\end{array}$ & $\begin{array}{l}-47.2 \\
-29.9 \\
-71 \cdot 5 \\
-66.6 \\
-92.5\end{array}$ & $\begin{array}{r}380 \\
358 \\
66 \\
27 \\
14\end{array}$ & $\begin{array}{r}190 \\
53 \\
64 \\
18 \\
15\end{array}$ & $\begin{array}{r}-50 \cdot 0 \\
-85 \cdot 2 \\
-3 \cdot 1 \\
-33 \cdot 3 \\
+7 \cdot 0\end{array}$ & $\begin{array}{l}\text { Poor } \\
\text { Poor } \\
\text { Intermediate } \\
\text { Good } \\
\text { Good }\end{array}$ \\
\hline
\end{tabular}

G.T.T. = Glucose tolerance test

-Testosterone therapy at time of measurement. 
There was a significant decrease in the mean S.E.R. following treatment $(P<0.01)$, and the percentage decrease in S.E.R. related well with the clinical response, being greater in those who had undergone successful pituitary ablation. In these five cases there was no correlation between the mean percentage decreases in S.E.R. and growth hormone concentrations as a result of treatment.

In Fig. 4 the S.E.R. is correlated with the log serum growth hormone and with the plasma cortisol and protein-bound iodine
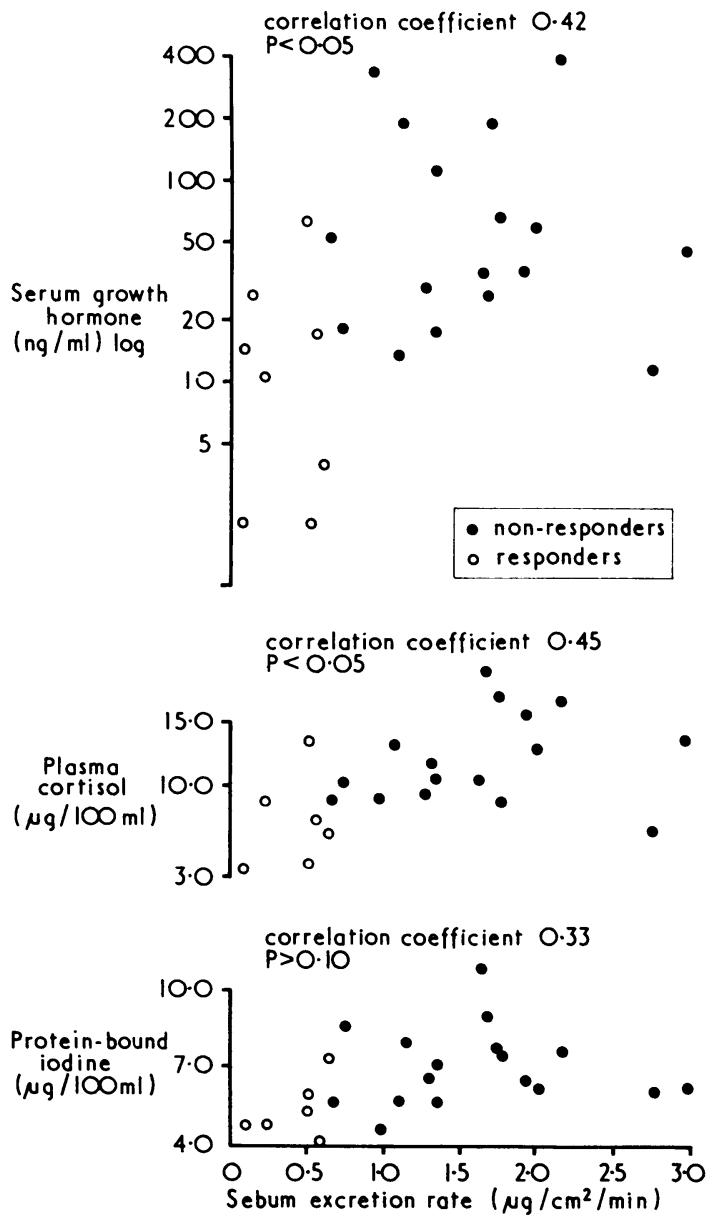

FIG. 4-Sebum excretion rate compared with serum growth hormone, plasma cortisol, and protein-bound iodine.

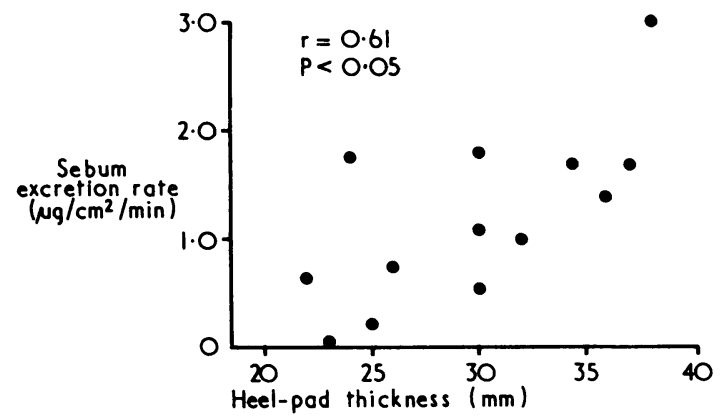

FIG. 5-Correlation between sebum excretion rate and heelpad thickness in acromegaly. concentrations for all patients. The correlations of S.E.R. with log serum growth hormone and with plasma cortisol were significant at the $5 \%$ level $(r=0.42$ and 0.45 respectively). The correlation with protein-bound iodine was not significant although the correlation coefficient was positive $(r=0.33)$.

The S.E.R. plotted against heel-pad thickness is shown in Fig. 5. The correlation was significant $(r=0.61, P<0.05)$.

The S.E.R. in all three patients receiving testosterone was lower than the mean S.E.R. of the patients in their respective clinical subgroups who were not receiving testosterone. Since testosterone stimulates sebum production it seems unlikely that this therapy affected our conclusions.

\section{Discussion}

Acromegalics have often been noted to have a greasy skin. This appearance may be attributed partly to the increased sweating in acromegaly, but we have found an increased rate of sebum excretion, despite the fact that facial hyperhidrosis tends to decrease the apparent S.E.R. as measured by the method we used.

We also found a significant decrease in the S.E.R. of the acromegalics after pituitary ablation, and the decrease was greater in the patients with a good therapeutic response to ablation than in those who had a poor result. A highly significant correlation between S.E.R. and clinical activity of the acromegalic process was found and this was better than the correlation between serum growth hormone and clinical activity. As might be expected, both plasma cortisol and protein-bound iodine decreased after pituitary ablation, but although the S.E.R. showed a general correlation with the serum growth hormone, plasma cortisol, and protein-bound iodine, a significant correlation coefficient was observed only with the first two of these. Such a general correlation night be predicted after widespread pituitary damage, and our data suggest that neither growth hormone, nor thyroid-stimulating hormone, nor adrenocorticotrophic hormone alone is responsible for the decrease in S.E.R. after pituitary damage. This is compatible with previous animal studies, which have shown that all three of these hormones affect sebaceous activity (Nikkari and Valavaara, 1969; Ebling et al., 1970; Thody and Shuster, 1970, 1971a, 1971b, 1972).

The present study thus indicates the importance of the pituitary gland in the regulation of sebaceous activity in the human. Our findings also suggest that the measurement of the S.E.R. may provide a useful index of activity of the disease process in acromegaly.

We are grateful to Professor D. Newell, of the department of medical statistics, University of Newcastle upon Tyne, for statistical advice. Thanks are also due to the Scientific and Research Subcommittee of the Royal Victoria Infirmary, and to the Wellcome Trust for financial help.

\section{References}

Cunliffe, W. J., and Shuster, S. (1969). British fournal of Dermatology, 81, 697.

Ebling, F. J., Ebling, E., Skinner, J., and White, A. (1970). Fournal of Endocrinology, 48, 73

Hartog, M., Gaafar, M. A., and Fraser, R. (1964). Lancet, 2, 376.

Lasher, N., Lorincz, A. L., and Rothman, S. (1954). Fournal of Investigative Dermatology, 22, 25.

Mattingly, D. (1962). Fournal of Clinical Pathology, 15, 374.

Nikkari, T., and Valavaara, M. (1969). Fournal of Endocrinology, 43, 113.

Steinbach, H. L., and Russell, W. (1964). Radiology, 82, 418.

Strauss, J. S., and Pochi, P. E. (1961). Fournal of Investigative Dermatology,

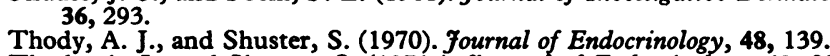

Thody, A. J., and Shuster, S. (1971a). Fournal of Endocrinology, 49, 325

Thody, A. J., and Shuster, S. (1971b). Fournal of Endocrinology, 50, 533

Thody, A. J., and Shuster, S. (1972). Fournal of Endocrinology. In press. 